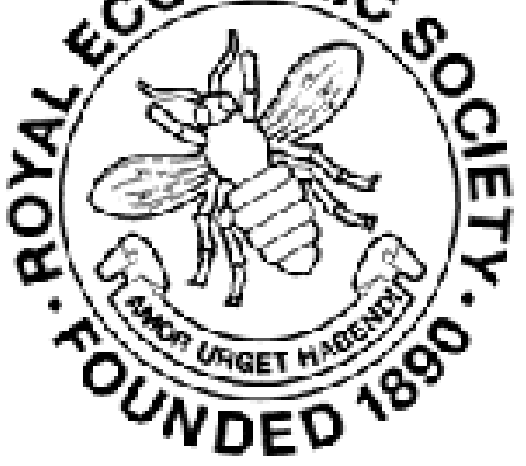

\title{
The "Beef Trust" and the United States Government
}

Author(s): Francis Walker

Source: The Economic Journal, Vol. 16, No. 64 (Dec., 1906), pp. 491-514

Published by: Wiley on behalf of the Royal Economic Society

Stable URL: http://www.jstor.org/stable/2221472

Accessed: 26-06-2016 03:55 UTC

Your use of the JSTOR archive indicates your acceptance of the Terms \& Conditions of Use, available at

http://about.jstor.org/terms

JSTOR is a not-for-profit service that helps scholars, researchers, and students discover, use, and build upon a wide range of content in a trusted digital archive. We use information technology and tools to increase productivity and facilitate new forms of scholarship. For more information about JSTOR, please contact support@jstor.org.

Royal Economic Society, Wiley are collaborating with JSTOR to digitize, preserve and extend access to The Economic Journal 


\section{THE ECONOMIC JOURNAL}

$D E C E M B E R, 1906$

\section{THE “BEEF TRUST" AND THE UNITED STATES GOVERNMENT.}

THE relations of the American meat industry and the Government of the United States have been of a peculiar and interesting character in recent years, and this, as well as the fact of the importance of this business in the markets of the world, makes appropriate a statement of the various phases of the situation.

The packers have been subjected to the scrutiny of the Governmental authorities, on the one hand upon charges of illegal combination and monopolistic control of prices, and on the other hand on charges of the unsanitary conditions in which they conducted their business. These two occurrences, although they had no direct or logical connection with each other, had probably some slight historical relation. The general feeling of hostility on the part of the public against these great organisations was based on the belief that the cattle producer and the cattle consumer were being exploited by the "packers" through monopolistic combination; that through the same monopolistic power they oppressed the packing-house workman, and imposed on the public products which, even if not themselves unwholesome, were produced under such unsanitary conditions that the health of the consumer was at least endangered. This subject possesses unity, therefore, only as it presents the successive phases of this conflict between Government and private industry.

The Meat Industry and the "Beef Trust."-The group of butchers and "packers" with whom the present article has to deal chiefly are popularly known in the United States as the No. 64.--VOL. XVI. 
"Beef Trust." The Beef Trust comprises a few large concerns, engaged in slaughtering and packing beef, pork, mutton, and other food products, whose aggregate output comprises a very large proportion of the total output of the United States, and nearly all of the business which requires shipment to distant (interstate or foreign) markets. The Trust, so-called, is often referred to as the "Big Six," or the "Big Four," according to the number of concerns under consideration. Their plants are located chiefly at central slaughtering points in the middle West.

This concentration of slaughtering in a few large cities is the result of various large economic movements. The occupation of the original prairie lands of the central Mississippi valley by farmers has driven the range business to the far West and southwest, where the lands are suitable for grazing, but seldom arable. These are the great breeding grounds for beef cattle, sheep, and also, to some extent, for hogs. The middle West, on the other hand, is the great grain and hay producing region, particularly maize, or Indian corn, which is the most important feed for fattening cattle and hogs for the market. In the far West and south-west most of the cattle are sent to corn States where they are put into the feed-lots for some months before shipment to market. These are the "Western" and "Texan" cattle which are distinguished from the "Native" cattle, which are bred in the corn States. Conveniently situated to this great corn belt are the several great cattle markets of the West, especially Chicago, Kansas City, St. Louis, Omaha, and St. Joseph. The stockman who has fattened his stock ships them by carload to these markets, where they are generally sold and purchased in a market, which, at least in form and in theory, is an open one. The cattle are generally sold by commission houses to which they have been consigned, and almost all of them are bought by the slaughtering establishments at those points. Some of the cattle, however, are bought for export on the hoof by other parties. The fact that there is a very great number of sellers and a small number of buyers, chiefly the buyers of the "Big Six," gives to the second group a decided advantage in determining prices, which, in case any collusion or agreement existed among them, would assume a decidedly monopolistic form. 'This, indeed, is often the theory of the stockmen, many of whom claim that there is a ring among the buyers, and that this ring manipulates the cattle prices, which, therefore, do not move in accordance with the natural relations of supply and demand.

On the other side, the packers are dealers in finished food 
products-fresh, salt, pickled, and canned meats, \&c. This trade is highly organised. The butchering and packing of meat comprises, however, only a small part of the activity of these great concerns - they are also engaged directly in the distribution of products. For this purpose, concerns like Swift and Company, and Armour and Company have their branch wholesale establishments in all parts of the United States, and often subsidiary corporations both at home and abroad. They also operate a vast number of so-called "private cars," which carry their products all over the United States.

This extension of their trade beyond the original manufacturing process is characteristic of several highly organised manufacturing industries at the present day (e.g., petroleum), and finds its reason for existence partly in technical and partly in commercial advantages derived therefrom. The transportation of fresh meat, for example, must be conducted by means of refrigerated cars, which necessitate frequent installations for icing purposes, \&c.; the sale of fresh meat, on account of its perishable character, can be most profitably conducted when there is a close correspondence maintained between the demand and supply in each local market, accompanied by prompt co-operation on the part of the transport agencies. This can be most securely established where the means of transport are at the disposal of the seller, and where he is kept in close touch with the local trade. The commercial advantage of such an organisation to the party introducing it is obvious, and such an organisation is almost necessary where there is competition, and it has been introduced by any one of the competitors. The system of selling the products directly in the local markets of consumption enables the packer to distribute his products more evenly and securely than if he sold it to middlemen who might switch their whole trade on any day. The local retail dealers could never put a packer in such a position so far as his whole business is concerned. Further, it brings them into the local market as sellers in much more advantageous position, because the buyers (i.e., the retailers) are necessarily much more numerous, and are consequently in a large measure obliged to pay what the packers dictate. If the supply of fresh meat from local butchers is small, and there is only one packer represented in a given locality, his power to fix prices becomes almost complete; if several great packers are established in such a market, and act in harmony, the same monopoly power appears. That such a condition of affairs is widely prevalent, is firmly believed by a large body of the consumers. 
Hence, the stockman and the public-i.e., the original producer and the final consumer-unite in denouncing the packers and their alleged monopoly. These attacks, in terms at least, have been directed more particularly against the beef trade, and hence this alleged combination is generally described as the "Beef Trust."

The "Beef Trust" is sometimes considered as combining four great concerns and sometimes six, depending chiefly on their importance and the degree of their supposed intimacy. The concerns in the "Big Four" are as follows:-First, Armour and Company, an exclusively family affair, with a capital stock of $\$ 20,000,000$, and an affiliated corporation, the Armour Packing Company, with a capital of $\$ 7,500,000$. These concerns in 1904 controlled great plants in Chicago, Kansas City, South Omaha, East St. Louis, and Fort Worth (Texas), and slaughtered (1903) 1,255,366 beef cattle, 3,451,892 hogs, and 1,496,984 sheep. Second, Swift and Company, a company having a capital stock of $\$ 35,000,000$, which is controlled by the Swift family, although there is a large outside interest. This Company in 1904 operated large plants in Chicago, Kansas City, South Omaha, East St. Louis, South St. Joseph (Missouri), Fort Worth, and South St. Paul, and slaughtered (1903) 1,578,215 beef cattle, 4,079,756 hogs, and 2,334,261 sheep. Third, Morris and Company, another exclusively family affair, with a capital stock of $\$ 3,000,000$, together with an affiliated concern called the Fairbank Canning Company, having a capital of $\$ 3,000,000$. This Company in 1904 operated plants in Chicago, East St. Louis, and South St. Joseph, and slaughtered (1903) 761,179 beef cattle, 1,247,393 hogs, and 739,237 sheep. Fourth, the National Packing Company, with a capital stock of $\$ 15,000,000$, a merger of several smaller plants of which control had previously been secured by the above-mentioned Companies. This Company operated in 1904 a number of plants, mostly small, in Chicago, Kansas City, St. Louis, Omaha, Hutchinson (Kansas), and New York, and slaughtered (1903) 848,884 beef cattle, 3,101,425 hogs, and 736,434 sheep. The "Big Six" includes two additional concerns which are unquestionably less closely related in their business operations than the "Big Four." They are as follows. First, Schwarzschild and Sulzberger Company, with a capital stock of $\$ 4,373,400$. This Company in 1904 operated plants in Chicago, Kansas City, and New York, and slaughtered (1903) 559,200 beef cattle, 623,598 hogs, and 494,642 sheep. Second, the Cudahy Packing Company, a family affair, with a capital stock of $\$ 7,500,000$. This Company in 1904 oper- 
ated plants in South Omaha, Kansas City, Sioux City (Iowa), and Los Angeles (California), and slaughtered (1903) 469,228 beef cattle, 1,347,675 hogs, and 364,200 sheep. ${ }^{1}$

The members of the Big Six are not confined in their operations to the slaughtering and packing business exclusively ; most of them do an extensive business in dairy products and in eggs and poultry, and in some cases, also, in fruits. The relative importance of these concerns to the beef industry may be more conveniently considered when we come to the results of the investigation of the Bureau of Corporations.

The Bureau of Corporations and the "BeEF Trust." Previous to the year 1904 there had been frequent complaints of the advance of the price of beef, and the "Beef Trust" was generally held responsible for the situation. In the first half of the year 1902 the price of cattle reached an extraordinarily high level, but declined greatly in the second half of the year, and this decline continued during the following year, so that in the last half of 1903 prices reached an extraordinarily low level. These facts, taken with the general belief that the prices of beef were abnormally high, caused great discontent, and developed a very lively agitation among the stockmen. Consequently, Mr. E. W. Martin, a Representative from South Dakota, introduced a resolution in the House (voted on March 7th, 1904), to the following effect :-

Resolved, That the Secretary of Commerce and Labor be, and he is hereby, requested to investigate the causes of the low prices of beef cattle in the United States since July first, nineteen hundred and three, and the unusually large margins between the prices of beef cattle and the selling prices of fresh beef, and whether the said conditions have resulted in whole or in part from any contract, combination, in the form of trust or otherwise, or conspiracy, in restraint of commerce among the several States and Territories or with foreign countries; also whether the said prices have been controlled in whole or in part by any corporation, joirt stock company, or corporate combination engaged in commerce among the several States or with foreign nations; and if so, to investigate the organisation, capitalisation, profits, conduct, and management of the business of such corporations, companies, and corporate combinations, and to make early report of his findings according to law.

In conformity with this resolution, the Bureau of Corporations, which is one of the divisions of the Department of Commerce and

1 The Beef Industry, pp. xix and $\mathrm{xx}$. 
Labour, undertook the investigation of the beef industry early in March, 1904.

The Bureau of Corporations, which is a recently established organ of administration, requires more particular description at this point because it is intended to exploit a new field of Governmental activity. This Bureau was established by Act of Congress on February 14th, 1903. This law provided for an officer entitled the Commissioner of Corporations, together with other officers, staff, and employees. The essential part of the Act which indicates the purpose of Congress is as follows:-

The said Commissioner shall have power and authority to make, under the direction and control of the Secretary of Commerce and Labor, diligent investigation into the organisation, conduct, and management of the business of any corporation, joint stock company or corporate combination engaged in commerce among the several States and with foreign nations excepting common carriers . . . and to gather such information and data as will enable the President of the United States to make recommendations to Congress for legislation for the regulation of such commerce, and to report such data to the President from time to time as he shall require; and the information so obtained or as much thereof as the President may direct, shall be made public.

The novelty of a Governmental organ of this character and its potential importance are obvious. The most authoritative statement of its purpose and function is found in the following excerpt from a report of the Commissioner of Corporations :-

The position of the Bureau at the time of its creation was unique. It owed its existence largely to a public feeling arising from unusual industrial developments. Public opinion thereon was vigorous, but confused and vague. In general, the tremendous concentration of industrial power, the obvious use, in many cases, of improper industrial methods of competition, and the instances of clearly unsound or fraudulent finance connected with corporations, led to the general belief that there had arisen a new industrial problem, a set of conditions not adequately met by existing laws. No solution of this problem had then received general acceptance, nor had the problem itself been clearly stated. Numerous experiments at solution had been made by way of anti-trust laws, but the admitted futility of most of these laws led only to the negative conclusion that such was not the way to treat the great industrial changes of which every one was cognisant.

Upon only one point can it be said that public opinion was fairly, clear and unanimous, and that point was the desire for " publicity" -in other words, the desire for information. It was not clearly 
understood to what use this information should be put, nor, indeed, what subjects it should cover; but the demand for accurate information was fundamentally sound. The policy of the Bureau has been framed in accordance with this demand. Its field may be divided into subjects relating to law on the one hand, and subjects relating to economic industrial facts on the other. It must examine and compare the statutes under which the corporations are doing business with industrial and statistical facts. ${ }^{1}$

The direction from the House that the Bureau of Corporations should investigate the beef industry was understood as an official investigation of a "trust," and the result of its activity was awaited with keen attention, not only on account of the popular interest in the particular subject matter of the investigation, but also, because the public was curious to see what could be accomplished by the Government in that direction.

The Bureau of Corporations proceeded at once to investigate the subject. It was quite evident that so far as prices and profits were concerned the most practicable way to obtain the former, as well as the only possible way to ascertain the latter, was by getting the information from the packers. The inquiry as to whether an illegal combination or conspiracy existed among them would naturally have to be prosecuted by different methods. Important statistical information on the slaughter industry is periodically published by the Bureau of Animal Industry of the Department of Agriculture, and is found also in various other Governmental records as well as in trade papers. Valuable material is also in the possession of the railroad companies. The price statistics of the trade journals and newspapers, however, though often a very fair reflection of the market, do not have a conclusive character on account of their indeterminateness as to quantity, especially when beef prices are under consideration. It was practically necessary to obtain the material of this character from the books of the packers.

The Commissioner of Corporations, therefore, requested the packers to furnish such information from their books as was deemed necessary, and they professed themselves in general as desirous of doing so, declaring (as they had frequently declared to the public) that they were not guilty of unfair price making or of illegal combination. They did not produce all their books, and they sometimes haggled about producing certain figures, or refused to give them, while others they were willing to show to

1 Annual Report of the Commissioner of Corporations, for the Fiscal Year ended June 30 th, 1905, pp. 5 and 6. 
the Bureau, but not for publication or transcription. Nevertheless, the Bureau obtained from them a vast amount of statistical material concerning the numbers and prices of cattle purchased, the amounts and prices of beef and other products sold, and the costs per head of various operations, \&c., most all of which were obtained by direct transcription from their books by Government agents and in such a comprehensive and voluminous form (including books of original entry) that any intelligent person who examined the material would not question their authenticity or their representative character. The price figures, moreover, were checked by comparisons with the prices received by commission houses for the sale of identical bunches of cattle, and by the prices of identical consignments of beef at various places, in such a manner that there could be little or no doubt of their reliability. The Bureau also diligently inquired into the facts regarding the existence or non-existence of an illegal combination among the packers. The investigations went beyond the slaughter industry proper, and included a very extensive study of the stock-raising business and the retail meat trade.

As a result of this investigation, the Bureau published certain partial results in a report of the Commissioner of Corporations on the Beef Industry, March 3rd, 1905. This report, as appeared in the letter of transmittal of the President to Congress, covered that part of the inquiry relating to "the prices of cattle and dressed beef, the margins between such prices, and the organisation, conduct, and profits of the corporations engaged in the beefpacking industry." The President's letter stated further-

In view of the fact that the Department of Justice is now engaged upon other matters involved in the resolution, the Secretary of Commerce and Labor cannot at this time report thereon.

This last statement referred to the omission of any discussion of the existence_of an illegal combination or conspiracy in restraint of trade on account of judicial prosecutions against the packers which were pending at that time. The Act which established the Bureau gave to the President the power to order the publication of such results as he deemed fitting, and it was in accordance with this provision of the law, and at the direction of the President, that no discussion of this subject was admitted into the published report of the Bureau.

It is not desirable to enter here upon a detailed discussion of the results of the investigation of the Bureau into the movements of the prices of cattle and beef, or the profits of the "Beef 
Trust," hence only a few salient points will be considered. The report made an estimate of the amount of business done by the "Beef Trust," first, in comparison with the total slaughter of beef cattle in the entire country, and, second, in comparison with the total slaughter at the eight principal western slaughter points. The former was found to be about 45 per cent., while the latter was found to be about 97.7 per cent. The report also made a very extensive comparison of the price movements of cattle and of beef. While the public information regarding cattle prices was not greatly in error, there was not much intelligent understanding about the prices which the packers received for beef. The man in the street generally thought of the price per pound of a porterhouse steak. The report showed, however, in a general analysis of the prices of cattle and beef, that the actual amount obtained from the sale of the dressed carcass (deducting transport costs) was invariably less than the amount paid for the live animalthis difference, and the profit of the packer, being covered by the other products, such as hides, fats, \&c. It was shown also, that, on account of the varying importance of the beef to the other products of a carcass, a margin reckoned between the pound price of cattle and the pound price of the dressed carcass was very misleading as to the real situation, on account of the great variations in the prices of hides and fat.

The Martin resolution, which was the immediate reason for the inquiry, alleged that unusually large margins existed between cattle and beef prices at the date of the resolution (March 7th, 1904). The figures of the Bureau showed that the margin for the period from July 1st, 1902, to July 1st, 1903, was $\$ 2.02$ per hundredweight, and for the succeeding year $\$ 2.10$ per hundredweight. In other words, although the prices of cattle had fallen greatly, as alleged, the prices of beef had fallen in about the same degree. $^{1}$

A more important feature of the report was the chapter on profits. The attempt was made to determine, as the House resolution requested, whether the profits on the beef industry had been unduly large during the period specified. Owing to the fact that the slaughtering concerns handled hogs and sheep, as well as beef cattle, this question could not be satisfactorily answered by an examination of the general financial accounts of the Company. The attempt was made, therefore, to separate the beef trade and reckon the profit per head of beef cattle, taking into account the live cost, the cost of slaughter, the value of the beef.

1 The Beef Industry, p. 268. 
and the value of the hides, fats and numerous other by-products. This calculation was made with great nicety on the basis of a large proportion of the total business of the great packers. For a number of plants of different concerns in various cities aggregate figures were shown of weight and price of live cattle, the weight and price of the beef sold from these same cattle, together with the proceeds from the hides and offal. The basis for cattle and beef being considerably different from that taken in the general analysis of the prices of cattle and beef, the results were not quite alike, but the general character of the results was the same. The remarkable feature about this analysis was the proof of the fact that the slaughter houses worked on a small margin per head. This may be illustrated by the computations given in the report for the year ending June 30th, 1904. The figures relate to 2,013,658 beef cattle. The average live weight was 1,115 pounds, the average cost was $\$ 4.15$ per hundredweight, or $\$ 46.23$ per head, and the total cost, including the cost of killing, was $\$ 48.19$. The average dressed weight of the beef carcass was 629 pounds, the average selling price (deducting transportation) was $\$ 6.25$ per hundredweight, or $\$ 39.26$ per beef carcass; the average yalue of the by-products was $\$ 9.75$ per beef carcass; the total proceeds were $\$ 49.01$ per beef carcass. This showed a profit of $\$ .82$ per head, or $\$ .135$ per hundredweight of dressed beef. ${ }^{1}$ The computations of the Bureau were checked by the bookkeeping records of the packers, which showed a true average profit of 99 cents per head, or 17 cents higher than that computed by the Bureau. ${ }^{2}$ These bookkeeping records of the packers were accepted by the Bureau as more accurate.

This profit of 99 cents per head seems very small, but, when the vast numbers of cattle are considered, it is not small. It would give for the total number of $2,013,658$ beef cattle covered by these accounts a total profit of $\$ 1,993,521$, and for the $6,836,733$ beef cattle slaughtered by these same concerns, in 1903, taking all their plants together, it would give $\$ 6,768,366$. This is a large profit, and it covers only the beef cattle business of the packers. If their hogs and sheep were also taken into account, it would be very much larger. The total profits of these concerns are not limited, however, to the slaughter industry. They make very large profits also in their private cars, as well as in the trade in other commodities which they handle, such as fruit and dairy products.

The report of the Bureau pointed out that the computation of

1 The Beef Industry, p. xxx.

2 The Beef Industry, p. xxxii, 
profit might be considered to underestimate the profits of the beef business in two ways; first, in not getting the profits of the subsidiary manufacturing processes so far as they applied to the beef business ; second, in not getting the profits of the private car lines so far as they handled the beef products. Both of these, however, were considered to be beyond the proper scope of the inquiry. The report made some estimates of these elements, and concluded as follows :-

It follows that in addition to the profit on cattle shown by the books of the packers, about $\$ 1$ per head, there may be an additional profit, more or less connected with the beef business, not to exceed at the outside 50 cents per head. ${ }^{1}$

Although the report of the Bureau did not present in detail the general financial operations of the concerns investigated, most of which are close corporations, it made the following comparison of its conclusions with the published reports of one of themSwift and Company :-

It appears, however, from examination of the accounts of Swift $\&$ Co. that the profit on beef bears about the same proportion to the total profit as the amount of the sales of beef bears to the total sales of the company. If it then be assumed that the plant investment required for the beef business is proportional to the amount of sales, it would appear that the profit on capital invested in the beef branch is approximately the same as in the business as a whole. Should this assumption be correct, the profits of Swift \& Co. on their beef business would be in the neighbourhood of 12 per cent. upon that proportion of their capital stock which is assignable to the beef industry. If, as appears probable, there is no overcapitalisation in the case of this company, the rate of profit on the true investment in the beef business would be approximately the same. In this connection it is of interest to note that the total sales of Swift \& Co. for the year 1904 were approximately $\$ 200,000,000$, and the total profits $\$ 3,850,000$, equal to about 1.9 per cent. on the volume of sales. ${ }^{2}$

The conclusion of the report on the matter of profits was, that a profit of $\$ 1.00$ per head on cattle, or of one-quarter of a cent a pound for dressed beef, though large, was not an undue profit for the packers. ${ }^{3}$ The Bureau did not go behind the records of the packers to discover whether there was any further profit in the beef business in the way of rebates on the transportation of beef. It is evident, however, that if such rebates existed in an important

\footnotetext{
${ }^{1}$ The Beef Industry, p. xxxiv, $\quad{ }^{2}$ Ibid, , p. 269, $\quad{ }^{3}$ Ibid., pp. 268 and 269 ,
} 
degree, the margin between cattle prices and beef prices, as well as the profit of the beef trade, would be considerably increased.

The report of the Bureau was received with great incredulity by a large part of the Press, and by a majority of the people. The glamour of the "Beef Trust," which exercises a great power throughout the West, was so great that authentic figures were of little avail to dispel the belief that the profits of the packers were of a phenomenal size. The critics of the report not only refused to accept the computations of the Bureau, but proceeded to make crude estimates and wild guesses of what the profits were. ${ }^{1}$ The more moderate ones guessed about $\$ 3.06^{2}$ profit per carcass, but the wilder guesses ranged up to $\$ 15.00$ on by-products alone $!^{3}$ The New York Evening Post ridiculed the idea that the packers made only 2 per cent. profits, ${ }^{4}$ and this was a favourite subject of derision. The Beef Report really said, however, that the packers reported about 2 per cent. profit on their sales. It can be safely asserted that it was never imagined by the Commissioner of Corporations that a profit on sales would be mistaken for a profit on capital, especially as in the body of the report the published profits of one of the large packers, amounting to a very substantial figure, were discussed in some detail. The man in the street, who was a little brighter than the rest, however, pointed out that a profit of 2 per cent. on sales was very likely a handsome profit, and, armed with this discovery, returned to attack the report for failing to see this. ${ }^{5}$

Criticism of this order revealed the slender basis of the critics' information or intelligence. Some competent and disinterested parties acquainted with the business were satisfied with the correctness of the report. No critic, however, was in a position to disprove the general correctness of the result, much less to make more accurate calculations, because nobody, unless he had access to the figures of the packers, could by any possibility have the necessary data. It is only fair to say that a good deal of the

1 One of the most ambitious efforts was that of Cuthbert Powell, in the Kansas City Journal (May 13th, 1905), which gave the total profit per head at $\$ 7.41$. J. J. Ryan, Secretary of the Corn Belt Meat Producers' Association, figured it out at about $\$ 8.00$ (Sioux City Tribune, April 1st, 1905).

2 New York American, March 5th, 1905.

3 Butler (Mo.) Times, April 20th, 1905.

4 New York Evening Post, March 4th, 1905.

5 Cf. the N. Y. Evening Post, March 4th, 1905, where a correspondent assumes a turnover every two (!) weeks-"at 2 per cent. on 'their total sales' they may eke out a paltry 52 per cent. per annum upon their capital" (sic). Cuthbert Powell puts it at 43 per cent. profit on $\$ 110,500,000$ of capital (Kansas City Journal, March 13th, 1905). 
criticism was based on the widely-published summary of the report, and this, partly on account of its necessary brevity, and partly because some statements were not explained and safeguarded as fully as they might have been, was more easily open to misconstruction.

In this respect, and probably in certain others, it was unfortunate also that the investigations of the Bureau were published in such a fragmentary form. As has been explained above, the fact that certain judicial prosecutions were under way made it seem desirable to the President to withhold the publication of any discussion concerning the existence of a combination, in order that the Bureau should not impede the operations of the Department of Justice. On the other hand, the absence of any thorough investigation of the transportation problem, particularly the questions of private car lines and of the rates of transportation, with all their interesting possibilities, was to be regretted. At the time the report was made, the question of the jurisdiction of the Federal Government over private car lines was under litigation, so that it would have been improper to assume such jurisdiction. Moreover, the proper boundaries between the activities of the Bureau of Corporations and the Interstate Commerce Commission were not so well understood as at the present time. The investigation of these subjects was omitted for these reasons.

Judicial Prosecution.-As stated above, the report of the Bureau of Corporations did not report on the question of the existence of a combination among the packers, because this question was at that time before the courts. The "Anti-Trust Act" of 1890 forbids any combination or conspiracy in restraint of trade under heavy penalties, irrespective of the question whether the combination is noxious or harmless from an economic standpoint. It was not proper that the executive branch of the Government should publish its conclusions, when it was a matter of criminal law which it is the duty of the courts to decide in the last resort, and which they had in this case already taken under consideration. It is not necessary to relate in detail the whole history of these proceedings, but certain results flowed from them which were of great importance to the Government, not only in respect to the "Beef Trust" in particular, but also in respect to legal action by the Government against any trust.

In May, 1902, a petition was filed in the Circuit Court of the United States in Chicago under the "Anti-Trust Act" of 1890, wherein it was alleged that seven corporations, one co-partnership, 
and twenty-three individuals had entered into a combination and conspired to suppress competition in the purchase of live stock and in the sale of beef, and to monopolise the trade by procuring rebates from the railroad companies on the shipment of fresh meat. The Supreme Court of the United States in January, 1905, issued a decree forbidding any such combination, and this decree was made perpetual. It was claimed by the Government that the packers were, nevertheless, continuing to conduct their business in the manner forbidden by the court. Hence, on March 20th, 1905, a grand jury in Chicago brought an indictment for violation of the "Anti-Trust Act" against most of the parties already defendants in the case. The defendants in this new issue objected to the indictment on various grounds, and, finally, on October 23rd, 1905, on the ground that they had received im. munity from such criminal persecution through the fact that they had furnished information to the Bureau of Corporations. This plea became the immediate question for the determination of the court, the trial of the charge that the packers had violated the " Anti-Trust Act," being dependent upon the decision on this matter.

It is important to consider the nature of this right which they claimed. The Constitution of the United States contains in the so-called " Bill of Rights," certain provisions which are intended to protect the individual from the abuse of Governmental power. One of these (fifth Amendment) contains the following provision, namely, "No person . . . shall be compelled in any criminal case to be a witness against himself." This rule of the common law, thus embodied in the Federal Constitution (and generally in the state constitutions also), is, like some other privileges under the common law, a frequent means of defeating the ends of justice, but such inconvenience is submitted to in the opinion that on the whole it works beneficently. It has been found, however, that in certain kinds of cases the advantage of thus protecting the individual is greatly outweighed by the disadvantage imposed on the community by this privilege of the individual to keep silence. Such cases arise, for example, in connection with unlawful discriminations in transportation. Abuses of great public moment of this sort should not be permitted to go uncorrected by the refusal of parties having knowledge of the facts to testify. A constitutional provision, however, cannot be disregarded, so that Congress, in connection with the law concerning " interstate commerce," provided for a means of obtaining evidence in such cases by requiring the witness to testify, even where 
he incriminated himself, by giving him as an equivalent immunity from prosecution in respect to any matter in which he might give such testimony. The first legislative effort of Congress to provide a substitute for the constitutional privilege ${ }^{1}$ was declared by the courts to be inadequate, i.e., the courts declared the law was unconstitutional, because it abolished a constitutional privilege without giving the witness an equivalent. ${ }^{2}$ The second attempt of Congress in this direction, ${ }^{3}$ however, was accepted by the courts as a satisfactory substitute. ${ }^{4}$ This power of the Interstate Commerce Commission to take evidence is established by the law in the following terms:-

That no person shall be excused from attending and testifying or from producing books, papers, tariffs, contracts, agreements, and documents before the Interstate Commerce Commission, or in obedience to the subpona of the Commission ... on the ground or for the reason that the testimony or evidence, documentary or otherwise, required of him, may tend to criminate him or subject him to a penalty or forfeiture. But no person shall be prosecuted or subjected to any penalty or forfeiture for or on account of any transaction, matter or thing, concerning which he may testify, or produce evidence, documentary or otherwise, before said Commission, or in obedience to its subpœna, . . . or in any such case or proceeding: Provided, That no person so testifying shall be exempt from prosecution and punishment for perjury committed in so testifying.

When the law establishing the Bureau of Corporations was framed, a provision was inserted giving to the Commissioner of Corporations the same power of getting information and taking testimony concerning matters within his jurisdiction as was given to the Interstate Commerce Commissioners in respect to theirs, and giving to those who testified the same immunities. ${ }^{5}$

The question before the court, therefore, was this: Had the Commissioner of Corporations, acting in conformity with the House resolution directing him to investigate the "Beef Trust," and in pursuance of his duties as prescribed by law, given to the packers the immunity from criminal prosecution, in respect to the charges upon which they were held, which was contemplated in the foregoing provisions of the law? This matter was not only

1 Act of February 4th, 1887, as amended March 2nd, 1889, and February 10th, 1891.

2 Counselman Case, 142 U. S., p. 547.

3 Act of February 11th, 1893.

${ }^{4}$ Brown v. Walker, 161 U. S. 591. Cf. also the recent case of Hale v. Henkel, 201 U. S. 43.

${ }^{5}$ Act of February 14th, 1903. 
of great importance on account of the case immediately before the court, but also as it affected other investigations of the Bureau of Corporations, the Interstate Commerce Commission, the Department of Justice, and perhaps other agencies of the Government for collecting information of importance to Congress or for general utility.

The trial in regard to the facts on this issue of the case was a protracted one, and, although certain of the packers gave testimony in regard to the facts which was in flat contradiction to the disinterested testimony of Government officials and agents, yet, according to the judge who tried the case, there was no important contradiction, except as to whether the Commissioner of Corporations had discussed with the packers the question of taking testimony under oath. In general, the facts were that the Bureau of Corporations had obtained information from the packers almost exclusively concerning prices, costs, profits, \&c., and had used them to show the relations of the prices of cattle and beef and the profits of the beef packers. There was no attempt to learn from the books of the packers any facts regarding railway rebates or other discriminations in transportation. The information was obtained without any compulsory process or the administering of oaths. The results of the investigation were (at the direction of the President) printed as a public document, and had been widely circulated by the packers. None of the data obtained from the packers had been furnished to the Department of Justice, except a table showing the total slaughterings, in which the practical constancy of the percentages of the packers indicated an agreement as to the quotas of production. This table was returned without examination, on account of the immunity plea made by the packers about the time it was furnished. None of the statements made in the report was of a character which would tend to disclose any criminal transactions.

The Government contended that the statutory immunity could be conferred only upon persons subpœnaed by the Commissioner of Corporations, and who subsequently might give testimony or evidence, in the legal sense, relating to the matter of the indictment. The defendants, on the contrary, held that any information which they furnished was necessarily furnished under the compulsion of law, although there was neither subpona nor oath. On account of the importance of the case, the AttorneyGeneral departed from the usual practice of his office, and appeared in person before the court to argue the Government's case. The general argument of the Government was, that the 
terms of the statute which provided for immunity declared that the immunity applied to natural persons giving testimony under a subpona, and that these were "words of art" with a definite legal meaning. ${ }^{1}$ The Government claimed that as the packers had given the information they furnished without subpœena or oath, and not in the formal manner of testimony, and without making any claim of immunity, they were not entitled to the privilege of immunity provided by the laws. The Attorney-General ridiculed the view of the defence that any information given to the Federal Government in conformity with law on a subject-matter of investigation would practically result in giving everybody who gave it complete immunity from prosecution by the Government for any offences committed with relation to it. The Attorney-General said :-

What would be the consequences? We might suppose that the confessions and statements in obedience to the law might be made at Washington, possibly to the Interstate Commerce Commission, possibly to the Commissioner of Corporations, possibly to the Attorney-General. This is a great discovery of my learned friend, for which uncounted generations of captains of industry will thank him. Washington will become the Alsatia to which they can resort for immunity for their offences. It will be much easier, much better, instead of running away from a subpœna, to run toward the Governmental agent and serve a confession upon him. . . .

It was in this connection that the Attorney-General described this way of getting immunity as an "immunity bath." 2

In spite of the ridicule of the Attorney-General, and to the astonishment of the general public, the court gave judgment in favour of the claim for immunity to the defendants as to the natural persons, but not as to the corporations. ${ }^{3}$ The essential sentences in the opinion were as follows:-

The immunity flows to the witness by action of law and without any claim upon his part.

I am of opinion that under this Act when the Commissioner of Corporations, who has power to compel, made his demand, it is the duty of the witness to obey. . . .

But it is insisted by the Government that they did not give under compulsion because they did not give what is known in law as under

1 The law also stated that if perjury were committed in giving such testimony the witness was not exempt from prosecution therefor.

2 Argument of the Attorney-General in United States $v$. Armour \& Company et al., \&c., Washington, 1906, p. 44.

3 The Hale case had decided that this immunity did not apply to corporations. 201 U.S. 43.

No. 64.-VoL. XVI. 
testamentary compulsion . . . and it is argued that testamentary compulsion means compulsion furnished by the subpœna and oath ....

I am clearly of opinion that the best judgment to be had from all the authorities is that the subpœna is a useless and superficial thing after the parties are together.

And I am also of opinion that under any one of these three acts in question-these three immunity laws in question-the production of books and papers would be legal evidence without the oath of any person where they are adduced as showing admissions against interest and against the party producing them. ${ }^{1}$

The effect of this decision was unfortunate in this respect, that it precluded all appeal to the Supreme Court, which, in case it had been rendered in the opposite sense, might have been made by the defendants. The packers, individually, were thus let off scot free. The indictments stand against the companies, but the policy of the Government as to their prosecution has not yet been made public.

This decision had, however, another immediate consequence of great importance. The interpretation of the immunity provision as made by Judge Humphrey in this case was not viewed with satisfaction by the public, nor by the administrative and legislative branches of the Government. Congress, therefore, promptly passed an Act defining such immunity as follows :-

That under the immunity provisions . . . immunity shall extend only to a natural person who, in obedience to a subpœna, gives testimony under oath or produces evidence, documentary or otherwise, under oath. ${ }^{2}$

Investigation of Sanitary Conditions.-The next phase in the relations of the packers to the Government was introduced to the public consciousness by means of a sensational novel. A writer named Upton Sinclair wrote a story called " The Jungle," 3 which gives the experiences of a Lithuanian family that settled in Chicago and got employment in the slaughter houses. Incidentally it gives a lurid account of the conditions of "Packingtown " and the seamy side of Chicago in general. As a novel, at least the first part, the book possesses undoubted merit, though at times rather crudely done. In the appalling picture which it draws of the conditions in Packingtown, one is reminded of Zola's

\footnotetext{
1 Argument of the Attorney-General, \&c. cit. sup. pp. 82-5.

2 An Act defining the right of immunity, \&c., June 30, 1906.

3 Doubleday and Page, 1906.
} 
"Germinal." The book concludes with an appeal for Socialism. The part of the story which is of interest in this connection, however, is that which describes the condition of things in the packing plants. It is not necessary to quote it in detail, but it is enough to say that it describes them as being not only extremely injurious to the workers but also as entirely devoid of proper attention to sanitary' methods of preparing the food. Not only are the conditions described as being generally filthy, but the accusation is made of systematic practices of utilising unhealthy cattle for food and of preparing the canned products from putrid meat and disguising the fact by artificial devices. These accusations were accompanied by such an apparent familiarity with the packing houses that, in spite of the author's very evident anti-capitalistic point of view, they tended to shock the reader and create serious suspicions as to the conditions of the packing industry. The Federal Government inspected this business to a certain extent, and the packers took great pains to advertise the fact, and often in a very misleading way, all of which was described in "The Jungle."

Although the general question of the inspection system was already under examination by the Federal Government before "The Jungle" appeared, the President directed Dr. Charles P. Neill, the Commissioner of Labour, and Mr. James B. Reynolds to make a special investigation on the spot. The report of Messrs. Neill and Reynolds, dated June 2, 1906, which was based on two and one-half weeks' observation of the conditions and methods prevailing in the industry at Chicago, resulted in a scathing condemnation of the packers. ${ }^{1}$

Some of the more flagrant eases of unsanitary conditions reported may be briefly noticed. The floors, tables, receptacles, $\& c .$, are described as being chiefly of wood, often rotten, and generally nasty with grease and dirt. The report makes a special complaint of the condition of the water-closets, describing them as improperly constructed, often merely partitioned off from the workrooms, unprovided with toilet paper, sometimes without lavatories, and never with soap or towels. In some cases the report states that the water-closets were so inconveniently situated that the workmen sometimes did not take the trouble to leave their workrooms. The handling of the meat was also said to be uncleanly, except for that part of the work between the killing floor

1 This report, together with the President's letter, the report of the Bureau of Animal Industry, and the testimony before the House Committee on Agriculture, may be found in "Hearings before the Commitee on Agriculture on the so-called Beveridge amendment," Washington, 1906. 
and the cooling rooms, which means practically the handling of fresh meat. In the boning room the workmen are said to climb over the piles of meat and to throw pieces they choose for cutting upon the floor. The clothing of these workers is said to be filthy. Meat scraps are said to be shovelled from dirty floors. The scraps were described as being sometimes " dry, leathery, and unfit to be eaten," and mixed with more or less rubbish. This stuff was used for canned goods, sausages, and the like, some of which is cooked and some not.

The report also made serious complaint of the method of labelling canned goods; the cans bore a label as follows: "The contents of this package have been inspected according to the Act of Congress of March 3, 1891. Quality guaranteed." As a matter of fact, the report states that the inspection being confined to the whole carcass, the Government has no knowledge whatever of the contents of the cans. It is also stated that the old canned stuff, sometimes two years old, was heated in the cans to "liven up" the contents, and new labels were placed thereon. The report complains also of very neglectful treatment of employees and the absence of ordinary decencies and comforts. It declared that the system of inspection prevailing, namely, compulsory inspection before slaughter and permissive inspection after slaughter, should be changed by reversing the rule. It also advocated the extension of inspection to all the processes of making food products and the requirement that all canned goods should bear a label showing the date of preparation and that this should not be defaced or altered. The report made some other recommendations, and declared that it would be necessary greatly to increase the number of inspectors to insure efficiency of inspection. ${ }^{1}$

The President referred this report to Congress, endorsing its findings and making a vigorous recommendation for an adequate inspection of all meat products. The President's letter and the report of Messrs. Neill and Reynolds, which had been awaited with great interest by the country, created a profound impression. Before Messrs. Neill and Reynolds made their investigation, a committee had been sent to examine the packing houses by the Department of Agriculture, in consequence of some complaints which had been made about the conditions prevailing there. This committee, which was composed of an expert on cattle diseases, a

1 The packers who had got wind of the general character of the report tried to induce Messrs. Neill and Reynolds to hold it up and give them thirty days to make improvements, after which it was proposed that they should again visit the packing houses and make the reformed conditions the basis of their report. Cf. "Hearings of the House Committee on Agriculture," pp. 96 and 97. 
chief inspector of cattle, and the Solicitor of the Department, also made a report which was made public at about the same time. ${ }^{1}$

This committee made a more exhaustive and detailed report of the conditions they found, going into the technicalities of cattle diseases and the methods of inspection on the one hand, and into the particular conditions of each packing house in detail on the other. So far as pointing out unsatisfactory conditions in particular rooms and particular instances is concerned, this report was quite as severe as the report of Messrs. Neill and Reynolds, but it also described the conditions in many more places as being satisfactory. It declared that they found it impossible to generalise on the subject. Even more numerous shocking quotations might be made from this report, therefore, but the general impression it gives of the conditions prevailing is certainly not so bad.

This report also criticised certain descriptions which had been printed about the Chicago packing houses, particularly in the London Lancet, and in "The Jungle." According to this report, the former contained many errors and exaggerations. Particularly it may be noted that the story of numbers of workmen meeting their death by falling into rendering tanks is declared to be founded according to the best information on a single instance occurring many years ago, in which instance the body of the victim was recovered. Concerning " The Jungle," they say :-

It is apparent that in his anxiety to be as sensational and "yellow" as possible the author has not only in this statement, but all through his book, selected the worst possible condition which could be found in any establishment as typical of the general conditions existing in the Chicago abattoirs, and has wilfully closed his eyes to establishments where excellent conditions prevail. ${ }^{2}$

The effect of these disclosures on public sentiment was such as to create a demand for the most sweeping kind of inspection law. Although the packers claimed to be for it, they tried to prevent the introduction of numerous proposed features and particularly the requirement that canned goods should be labelled with the date of manufacture, and that they should pay the cost of inspection. ${ }^{3}$ In respect to paying the costs of inspection the stockmen sided with the packers, fearing that if it were put on the packers it would be shifted to their shoulders. ${ }^{4}$ On the other side there was a considerable sentiment in favour of putting it on the packers because their shortcomings made inspection necessary,

1 The report is dated April 3, 1906.

3 " Hearings," \&c., p. 89.

2 P. 349.

4 " Hearings," \&c., p. 216. 
and because, as many believed, they derived a positive financial and commercial advantage from Government inspection, both in the labour performed and in the advertisement that the Government labels gave to their goods. A law was finally agreed on which received the approval of Congress and the President. ${ }^{1}$

The principal features of this inspection law are as follows: The Secretary of Agriculture is empowered to establish a system of inspection for all slaughtering and packing houses which prepare meat products for interstate or foreign commerce. ${ }^{2}$ The law provides for a post-mortem inspection, and the rejection of all carcasses or parts of carcasses that are " unsound, unhealthful, unwholesome, or otherwise unfit for human food." This inspection continues throughout the entire process, and none of the products are allowed to pass unless properly inspected and labelled. False descriptions of food products are forbidden, though this does not extend to the prohibition of trade names which are usual and not false and deceptive. The Secretary of Agriculture is authorised to establish rules for proper sanitation of slaughtering and packing houses and to pass the products of only those establishments which conform thereto. Persons are forbidden to offer for transportation in interstate or foreign commerce any such products as have not passed Government inspection, and carriers in interstate and foreign commerce are forbidden to accept them. The Secretary of Agriculture is authorised to inspect all cattle, sheep, swine, and goats offered for export, and to ascertain if they are diseased. No clearance shall be given to vessels carrying such animals, unless a certificate of health is shown, or the Secretary of Agriculture waives such requirement. A similar rule is provided for food products prepared from such animals. The law provides, in general, that the law shall not extend to farmers slaughtering stock on the farm nor to retail butchers. Three million dollars are appropriated to carry out the provisions of the Act.

In accordance with this law, the Secretary of Agriculture issued on July 25, 1906, elaborate regulations concerning inspection,,$^{3}$ certain features of which are of interest here. The rules established for the sanitation of packing houses are quite particular

1 An Act making Appropriations for the Department of Agriculture, approved June 30, 1906.

2 Owing to the peculiar character of the Constitution of the United States, the Federal Government can exercise police power over this industry only through the clause that gives it control of "commerce among the States, and with foreign nations."

3 Regulations Governing the Meat Inspection of the United States, Department of Agriculture, Washington, 1906. 
in their requirements concerning the cleanliness of the rooms, floors, utensils, and the clothings and persons of employees, also concerning ventilation, the prohibition of the employment of persons known to have communicable diseases, \&c. An antemortem inspection is established, and minute provisions are made concerning the condemnation of cattle in the post-mortem examination. Special provisions are made concerning the use of dyes, chemicals, and preservatives. Regulation 39 reads in part :-

No meat or meat food product for interstate commerce, or for foreign commerce except as hereinafter provided, shall contain any substance which lessens its wholesomeness, nor any drug, chemical, or dye (unless specifically provided for by a Federal Statute), or preservative, other than common salt, sugar, wood, smoke, vinegar, pure spices, and, pending further inquiry, saltpeter.

No provision was made, either in the Federal law or in the regulations of the Secretary of Agriculture, concerning the dating of canned food products. The general belief seems to be that canned products, if well packed, will keep indefinitely without deterioration.

To one who has no technical knowledge of meat inspection, the Federal law and the regulation of the Department of Agriculture seem well contrived to procure satisfactory results, and there seems to be no reason for doubting that it will be executed with integrity and efficiency. Although the American meat trade, particularly in canned goods and other packing-house products, suffered very much from the exposures described above, the confidence of the public will probably be restored before long. In foreign countries the general examination of conditions prevailing in them, which has been suggested by the developments in America, have probably shown that the conditions in Chicago were by no means exceptionally bad. It is probably true that in some other large packing centres in the United States the conditions have been generally superior to those in Chicago, as the plants are generally more modern and the condition of the employees much better.

One encouraging thing was demonstrated by this meat scandal and that is, that the Government and the people of the United States are not dominated by purely commercial interests (as is often asserted), and that when an abuse clearly appears and an adequate remedy is found, reform will be made as quickly as possible. The haste with which the packers have attempted to meet the new requirements of the law, in view of their vaunted 
power, is a striking evidence of the commercial influence of public opinion. An equally encouraging sign is the Government's independence of uninformed public opinion, or prejudice, and the impartiality of its administration. In the report on the "Beef Trust " the country was shown that the popular opinions respecting the wholesale prices of beef and the profits in the beef industry were founded on ignorance and error. At the same time it prosecuted the packers for alleged violation of the anti-trust law. The failure of the Government in that undertaking was not due to any lack of zeal and energy, but to a technical legal obstruction which no one could foresee-the opinion of one judge on a new point of law ; and if that obstruction had not appeared, the case would have been fought to a finish on its merits.

Francis Walker 